DOI: 10.12731/2077-1770-2021-13-4-592-604

UDC 811

\title{
COMPARATIVE ANALYSIS OF ORIGIN AND EVOLUTION OF SIGN LANGUAGES
}

\section{Galieva D.A., Naurazbaeva L.V.}

The object of the research is to analyze sign languages which have been an essential aspect of communication throughout human history of the disabled. It aims to examine the main stages of development of sign languages.

The subject of the research is sign languages of the deaf and the hearing impaired.

The research methods include a theoretical analysis of the works of Russian and foreign linguists and the method of comparative analysis.

The results of the analysis of the main stages of sign languages let us come to the conclusion that the status of sign languages which have passed the historical gradual development responding to the needs of a developing society. The following aspects such as the verbal national language, linguistic schools, the culture of the people have a huge impact on the formation and development of any sign language. It should be noted that sign languages as well as verbal languages are related to each other. They are functionally complete (natural) languages with their own, sometimes rather complex internal mechanism.

Keywords: sign language; dactylology; iconicity; evolution of language; typology

\section{СОПОСТАВИТЕЛЬНЫЙ АНАЛИЗ ВОЗНИКНОВЕНИЯ И РАСПОСТРАНЕНИЯ ЖЕСТОВЫХ ЯЗЫКОВ}

\author{
Галиева Д.А., Науразбаева Л.В.
}

Цель научного исследования - рассмотреть вопросы происхождения и развития жестовых языков, неразрывно связанных с исто- 
риейлюдей с ограниченными возможностями. Для достижения цели исследованы этапы исторического развития жестовых языков.

Предметом научной работы являются жестовые языки глухих и слабосльимащих людей.

При изучении вопросов жестовых языков применялись такие методы, как теоретический анализ работ отечественных и зарубежных лингвистов, посвященных данной проблеме, а также метод сравнительного анализа.

Результаты анализа основных этапов развития жестовых языков позволяют сделать вывод, что становление знаковых языков прошло исторический путь постепенного развития, активно реагируя на потребности развивающегося общества. Такие аспекты, как словесный национальный язык, лингвистические школь, культура народа, оказывают значительное влияние на развитие любого жестового языка. Жестовые языки, также как и звуковые, связаны между собой отношениями родства. Они являются функиионально полноценными (естественныли) языками с собственным, иногда довольно сложным внутренним механизмом.

Ключевые слова: жестовый язык; дактилология; иконичность; эволюиия языка; типология

Currently, there have been major positive changes in sign languages, as many laws have emerged to protect the language and culture of the deaf. In addition, there is a growing awareness in the world that everyone has the right not only to a favorable economic and social environment, but also to the right to participate in the political life of society. Through interaction with various structures, deaf people can gain access to the legal sphere, including the police and courts, use necessary information, be able to fully participate in civic life, in social and cultural spheres, as well as participate in the political and public life of their country.

The object of our research is sign language, since "language is real and objective in its complex whole and in all its aspects, parts and structural units. ... therefore, the language has been and remains the subject of scientific knowledge" [8, p. 9]. Indeed, language is a complex sign 
system created in a natural or artificial way. As a result of its constant development, neologisms and borrowings appear, and some words and expressions, on the contrary, lose their relevance and become archaisms, grammatical forms change, etc. Sign language is also subject to similar changes.

Recently, the study of gestures has become an independent science, therefore, during this period, the formation of a new communication system can be traced. Accordingly, the purpose of this article is to study the history of the origin of sign language and its use in various fields of activity, in particular, in jurisprudence.

From a historical point of view, the origin and formation of sign languages, go back to ancient times. Verbal or sound language appeared much later. The earliest people's attempts to establish communication (still nonverbal by that time) testify that sign language was formed from instinctive, involuntary movements. The etymology of some gestures, such as images of animals, household items, etc. is quite easy to trace, based on their iconicity.

The beginning of the systematization and active development of national sign languages dates back to the $8^{\text {th }}$ century, when industrialization in Europe caused an increase in the number of deaf people living in large cities. Undoubtedly, an important stimulus for the formation and spread of sign languages was the appearance of educational centers for children with various hearing impairments in France (under the leadership of Abbot Charles-Michel de l'Epee) and Germany (under the leadership of Samuel Heinicke) at the end of the $18^{\text {th }}$ century. At that time, the primary task was to teach deaf children to write. The natural everyday gestures of the national communities of the deaf gave rise to an artificially created sign interpretation of the French and German languages.

Based on the above, it is logical to assume that the pedagogical successes of the German and French schools for the deaf and dumb served the emergence of educational institutions in other countries. At the same time, either surdopedagogical concepts (England) or the methodology as a whole (USA) were borrowed, including the sign language itself.

Thus, the first school that opened in 1817 in the United States in 
Hartford (Connecticut) used the French method of teaching deaf children. This influenced the similarities between Amslen, American Sign Language (ASL) and French Sign Language (LSF, Langue des Signes Française), and, on the dissimilarity with British Sign Language (BSL).

There are hundreds of sign languages, dialects, adverbs, slangs, etc. in the world today. The genealogical classification of sign languages, along with verbal languages, divides them into groups and families. However, it is quite difficult to trace the degree of kinship of sign languages, due to their rapid and spontaneous development. If the Russian sound language belongs to the East Slavic group of the Indo-European family, then the Russian sign language belongs to the French family, which includes such languages as Flemish, American, Dutch, Brazilian, etc. The specificity and originality of each national language are preserved.

Research has shown that the historical links between sign languages are explained, among other things, by world politics and the export of education. In particular, the historical legacy of the Habsburg Empire led to a direct connection between the sign languages of Austria, Germany and Hungary. The emergence of new dialects in Taiwanese sign language, similar to the sign language of the Japanese, was the result of the Japanese occupation of Taiwan. The export of educational systems was also greatly influenced by the religious and missionary activities of the people. Most countries in Europe and North America have been influenced by the French education system for the deaf. Swedish and Portuguese sign languages interacted as a result of the establishment of a school in Lisbon by deaf Swedish teachers in 1824. Irish monks who taught deaf children have influenced the sign languages of India, Australia, South Africa and other countries. [4, p. 39]

In the modern world, despite the prevailing opinion about the uniqueness of sign language, there is no universal sign language. There are over 100 sign languages that are used for communication between people with speech and hearing impairments. Thus, a foreigner from the United States of America cannot understand a deaf person from Russia. For example: the gesture "evil" as an adjective in Russian sign language 
will be interpreted as "Sorry, Pardon, Excuse me" in American sign language.

It should be noted that sign speech is different from verbal speech. For example, the verb "to go" in Russian sign language is conveyed in different ways, depending on who or what is coming - time, person, rain, and synonymous concepts are often denoted by common gestures flame, bonfire, fire. And non-verbal means of communication, such as articulation, facial expressions, pantomime, expressing feelings and mood complement and clarify gestures.

Every movement of the hand in sign language means a certain concept. However, sign language should not be associated with body language, which is also a way of non-verbal communication. So, the reading skills of the latter: facial expressions, emotions, gestures, proxemics, kinesics and other external reactions are widely used in psychology.

Therefore, everything depends on the history of the emergence of a particular language. The following aspects such as the verbal national language, linguistic schools, the culture of the people have a huge impact on the formation and development of any sign language. Over time, sign language becomes more complex, and gestures acquire different meanings.

Each sign language of the deaf has its own name: the language of the deaf in the United States is called Amslen (AMerican Sign LANguage); the British Sign Language family uses the term "BANZSL" (British, Australian and New Zealand Sign Language). Despite the verbal language (German), Germany and Austria actually use different sign languages that are not related to each other. Thus, Austrian Sign Language (German Österreichische Gebärdensprache, ÖGS) and German Sign Language (Deutsche Gebärdensprache, DGS).

In addition to sign speech, dactylology is also referred to as specific means of communication. Each national sign language has its own unique dactyl alphabet, it is used in the process of communication when designating neologisms, names, names of cities.

It is still unknown when dactylology originated. It is generally accepted that the first data on the dactyl alphabet were obtained in the 16th 
century. There is no exact confirmation of how the alphabet originated; some scholars assign the role of monks who took a vow of silence. Others believe that Spanish philosophers and monks used the dactyl alphabet when teaching the deaf and dumb.

It is known that Pedro Ponce de Lyon, a Spanish monk, successfully used dactyl speech in teaching deaf children. However, the dactyl alphabet was published only a hundred years later in Joan Pablo Bonet's book On the Nature of Sounds and the Art of Teaching the Deaf to Speak. In Russia, the dactyl alphabet began to be used only in the $19^{\text {th }}$ century.

We believe that a key step towards the self-determination of sign languages was the emergence of the World Federation of the Deaf (WFD) in 1951. September 23, 1951, an international non-governmental organization (an association of organizations from 135 countries) was created in Rome to represent and promote the rights of the deaf. The mission of the World Federation, which still carries out its functions, is to support the observance of human rights for people with hearing impairments, the possibility of high-quality and equal access to all spheres of life: self-determination, sign language, education, employment and social life.

In 1975, at the World Congress of the Deaf, the International Sign Language or Gestuno was adopted and ratified, which became an international sign system and united the Federation of the Deaf. International Sign Language has facilitated communication between deaf people from different countries both in informal settings, for example, youth forums or festivals, and at official events, in particular, the Deaflympics, world congresses on the problems of the deaf, etc. The International Sign Language Dictionary, also created by the World Federation of the Deaf, contains 1,500 gestures used in various national systems.

The history of the emergence of Russian sign language dates back to the $19^{\text {th }}$ century. It should be noted that before the official opening of the first schools for the deaf and dumb, children with hearing impairments were trained and brought up in monasteries, where the method of total communication was used, that is, a combination of sign and verbal languages.

In 1806, the first school for the deaf was opened in Pavlovsk (near St. Petersburg), using the French method of teaching deaf children in Rus- 
sia. In 1860 the school moved to Moscow and began to work according to the German method.

For a more complete description of the issue of the development of the Russian sign language in Russia, the works of Russian scientists were studied. Thus, the first scientific studies of the Russian sign language in Russia were carried out by the director of St. Petersburg School, teacher of the deaf V.I. Fleury (1800-1856). The book by V.I. Fleury The Deaf and Dumb ... (1835) gives the first lexical and lexicographic description of Russian sign language and includes the first Russian sign language dictionary, consisting of gestures collected directly from the deaf and dumb. The author identifies three types of sign speech and conducts a comparative analysis of Russian gestures and the gestures used at Paris Institute for the Deaf. Based on the typology of gestures V.I. Fleury is the first to describe the features of the linguistics and syntax of Russian sign language, taking into account the meaning of the non-manual component of the gesture.

Since almost all educational institutions in the Russian Empire were established by former teachers or graduates of St. Petersburg School, sign language was used in Russia until 1917 when teaching deaf people.

At the end of the $19^{\text {th }}$ century, Europe began to adhere to the oral method of teaching deaf people, which could not but affect the attitude towards sign language and the quality of education for the deaf.

The teaching methodology for the deaf in Europe has also influenced educational activities in Russia. Outstanding scientist, teacher of the deaf N.M. Lagovsky (1863-1933) considered the sign language of the deaf, studied the specifics of its natural and artificial forms. However, unlike V.I. Fleury, he believed that sign language has no grammatical forms and rules. N.M. Lagovsky adhered to an exclusively oral method using the dactyl alphabet. However, researchers with significant working experience with deaf children have come to the conclusion that sign language is necessary as an educational aid.

L.S. Vygotsky (1886-1934), a great Russian psychologist and defectologist, first supported N.M. Lagovsky's methods. But, after some time, at the beginning of the 1930s, on the basis of practical experience 
and research, the scientist comes to the conclusion that sign language is a complex and peculiar linguistic system.

The ideas of L.S. Vygotsky were developed in scientific research of teachers of the deaf G.L. Zaitseva, N.G. Morozova, R.M. Boskis, who tried to consider sign language experimentally for the first time in Russia. The scientific work by N.G. Morozova and R.M. Boskis "On the development of mimic speech" emphasizes that sign language has its own grammar, which is different from the grammar of the Russian language.

At the same time, the well-known teacher of the blind, deaf and dumb I.A. Sokolyansky (1889-1960) considered it was necessary to use sign language in teaching the deaf, especially at the initial stage of training. According to the scientist, deaf people should be equated with foreigners, and their language should be considered as a peculiar, but typical language system that you need to know, you need to study. I.A. Sokolyansky considered sign language as the native language of deaf people.

The creation of the All-Russian Society of the Deaf and the emergence of regional branches in the $20 \mathrm{~s}-30 \mathrm{~s}$ of the $20^{\text {th }}$ century contributed to the formation of the Russian system of sign communication. Hearing impaired people all over the country began to communicate, organize scientific conferences, sports competitions.

In the Soviet period, thanks to the active involvement of the deaf in the social and political life of the country, such a concept as sign language interpretation emerged. A huge contribution to the system of training specialists in sign language interpretation in the Soviet Union was made by I.F. Geilman (1923-2010), who compiled the first voluminous dictionary of Russian sign language and international sign language (Gestuno). In 1957, the first sign dictionary was published under the direction of Joseph Geilman, and the centralized training of sign language interpreters began.

In all regions of the former Soviet Union, except for the Baltic States, the majority of deaf citizens have a single sign language. However, it should be recognized that along with the common language there are also various local dialects. Dialectal differences in vocabulary are especially noticeable. 
According to I.F. Geilman's methods sign language interpretation received the name "tracing interpretation" or "tracing sign speech" $[3$, p. 192]. The researcher believed that "the only language of the human community capable of serving as a full-fledged means of communication between people has always been the language of words" $[1$, p. 3], which means that the interpretation should be based on the verbal language.

In the second half of the $20^{\text {th }}$ century (1992), Doctor of Pedagogy, professor, researcher of sign language, culture and history of the deaf G.L. Zaitseva (1934-2005) developed a standard for Russian sign language and opened the first Moscow bilingual gymnasium for deaf children. For many years G.L. Zaitseva was engaged in the pedagogy of deaf people and practical research of Russian sign language, and it was she who managed to make significant progress in the field of Russian surdopedagogy. Most of the teachers of the countries of the former USSR and the Eastern European countries of the post-Soviet space use her methodological developments.

The status of sign language in Russia was legislatively approved in 2012: Russian sign language was defined as the language of communication in the presence of hearing and (or) speech impairments. The recognition of Russian sign language by official authorities is undoubtedly an important sociolinguistic factor. A positive change in the status of sign language contributes to the organization of uniform training programs, creation of teaching aids, teachers' training in state educational institutions. The development in the field of special terminology of Russian sign language ensures the interaction of the hearing-impaired and the hearing-and vision-impaired with the state authorities.

In our opinion, Russian sign language is a natural language, a full-fledged linguistic system that develops spontaneously and is assimilated by deaf people as a native language. However, it should be recognized that there is an artificial communicative system - tracing sign speech, which repeats the grammar of the verbal Russian language. 


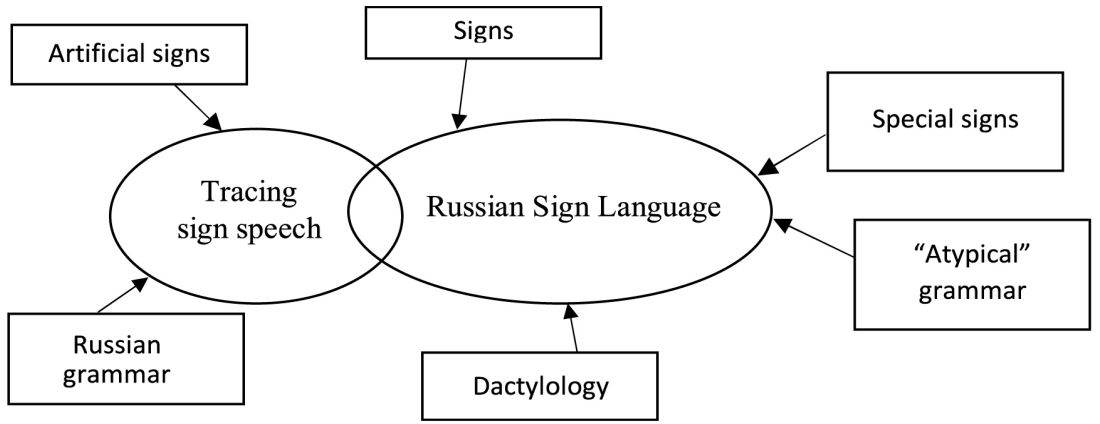

Thus, throughout almost the entire history of teaching and upbringing of the deaf, Russian sign language was not perceived as an independent linguistic system in our country. Initially, sign language was used to teach the Russian language (written and spoken) to the deaf, later it was declared "unsuitable".

\section{References}

1. Geyl'man I.F. Ruchnaya azbuka i rechevye zhesty glukhonemykh [Manual alphabet and speech gestures of the deaf and dumb]. Moscow: KOIZ, 1957, $596 \mathrm{p}$.

2. Dimskis L.S. Izuchaem zhestovyj jazyk [Learning Sign Language]. Moscow: «Akademija» Publ., 2002, 128 p.

3. Zaytseva G.L. Zhestovaya rech'. Daktilologiya: Ucheb. dlya stud. vyssh. ucheb. zavedeniy [Sign speech. Dactylology: textbook for university students]. Moscow: VLADOS Publ., 2000, 192 p.

4. Zaytseva G.L., Frumkina R.M. Psikholingvisticheskie aspekty izucheniya zhestovogo yazyka [Psycholinguistic aspects of studying sign language]. Defektologiya [Defectology], 1981, no 1, pp. 14-21.

5. Islamova E.A. Vvedenie v yazykoznanie: uchebnoe posobie [Introduction to linguistics: manual]. Kazan': KFU Publ., 2016, 81 p.

6. Kucheryavaya T.L. Problemy professional'no-orientirovannogo obucheniya inostrannomu yazyku studentov neyazykovykh spetsial'nostey [Problems of professionally oriented teaching of a foreign language to students of non-linguistic specialties]. Teoriya i praktika obrazovaniya $v$ sovremennom mire: materialy I Mezhdunar. nauch. konf. (Sankt-Peterburg, fevral' 
2012 g.) [Theory and practice of education in the modern world: materials of the I International. scientific conference (St. Petersburg, February 2012)], vol. 2. St. Peterburg: Renome, 2012, pp. 336-337. URL: https:// moluch.ru/conf/ped/archive/21/1783/ (accessed 29 July 2021).

7. Naurazbaeva L.V. Osobennosti obucheniya sotrudnikov organov vnutrennikh del daktil'noy $i$ zhestovoy rechi: uchebno-metodicheskoe posobie [Peculiarities of training dactyl and sign speech to police officers: training manual]. Ufa: Ufimskiy YuI MVD Rossii, 2018. URL: http://www/ufali. ru/eios/ebs/Elektronnaya biblioteka/141.pdf (accessed 17 July 2021).

8. Petrova E.A. Istoki $i$ vektory logiko-kognitivnogo napravleniya $v$ izuchenii yazyka: monografiya [The origins and vectors of the logical-cognitive direction in the study of language: monograph]. Ufa: UYuI MVD Rossii, 2013, 127 p.

9. Serebrennikov B.A. Territorial'naya i sotsial'naya differentsiatsiya yazyka [Territorial and social differentiation of language]. Obshchee yazykoznanie. Formy sushchestvovaniya, funktsii, istoriya yazyka [General linguistics. Forms of existence, functions, history of language]. Moscow: Nauka Publ., 1970, pp. 451-501.

10. Solomonik A.B. Filosofiya znakovykh sistem i yazyk [Philosophy of sign systems and language]. Minsk: MET, 2002, 408 p.

11. Teoriya i praktika russkogo zhestovogo yazyka: uchebnoe posobie [Theory and practice of Russian sign language: manual]. Moscow: DGSK MVD Rossii, 2018, 174 p.

12. Kharlamenkov A.E. Teoriya russkogo zhestovogo yazyka: uchebnik dlya vuzov [Theory of Russian sign language: textbook for universities]. Moscow: Yurayt Publ., 2021, 171 p. URL: https://urait.ru/bcode/479066 (accessed 29 July 2021).

13. Corson H.J. Deaf studies: A framework for learning and teaching. Deaf Studies for educators. Washington DC: Gallaudet University, College for Continuing Education, 1992, pp. 7-16.

14. Stokoe W.C. Sign language structure: an outline of the visual communication systems of the American deaf. Journal of Deaf Studies and Deaf Education, 2005, vol. 10(1), pp. 3-37.

15. Wixtrom C. Two views of deafness. Deaf American, 1988, 38(1), pp. 3-10. 


\section{Список литературы}

1. Гейльман И.Ф. Ручная азбука и речевые жесты глухонемых. М.: КОИЗ, 1957. 596 с.

2. Димскис Л.С. Изучаем жестовый язык: Учеб. пособие для студентов дефектол. фак. высш. пед. учеб. заведений. М.: Издательский центр «Академия», 2002. 128 с.

3. Зайцева Г.Л. Жестовая речь. Дактилология: Учеб. для студ. высш. учеб. заведений. М.: ВЛАДОС, 2000. 192 с.

4. Зайцева Г.Л., Фрумкина Р.М. Психолингвистические аспекты изучения жестового языка // Дефектология. 1981. №1. С. 14-21.

5. Исламова Э.А. Введение в языкознание: учебное пособие. Казань: КФУ, 2016. $81 \mathrm{c.}$

6. Кучерявая Т.Л. Проблемы профессионально-ориентированного обучения иностранному языку студентов неязыковых специальностей // Теория и практика образования в современном мире: материалы I Междунар. науч. конф. (г. Санкт-Петербург, февраль 2012 г.). Т. 2. СПб: Реноме, 2012. С. 336-337. URL: https:// moluch.ru/conf/ped/archive/21/1783/ (дата обращения: 29.07.2021).

7. Науразбаева Л.В. Особенности обучения сотрудников органов внутренних дел дактильной и жестовой речи: учебно-методическое пособие. Уфа: Уфимский ЮИ МВД России, 2018. URL: http://www/ ufali.ru/eios/ebs/Эл. библиотека/141.pdf(дата обращения: 17.07.2021).

8. Петрова Е.А. Истоки и векторы логико-когнитивного направления в изучении языка: монография. Уфа: УЮИ МВД России, 2013. 127 с.

9. Серебренников Б.А. Территориальная и социальная дифференциация языка // Общее языкознание. Формы существования, функции, история языка. М.: Наука, 1970. С. 451-501.

10. Соломоник А. Философия знаковых систем и язык. 2-е изд., доп. и испр. Минск: МЕТ, 2002. 408 с.

11. Теория и практика русского жестового языка: учебное пособие. М.: ДГСК МВД России, 2018, 174 с.

12. Харламенков А.Е. Теория русского жестового языка: учебник для вузов. М.: Изд-во Юрайт, 2021. 171 с. ISBN 978-5-534-14700-1. URL: https://urait.ru/bcode/479066 (дата обращения: 29.07.2021). 
13. Corson H.J. Deaf studies: A framework for learning and teaching // Deaf Studies for educators. Washington DC: Gallaudet University, College for Continuing Education, 1992, pp. 7-16.

14. Stokoe W.C. Sign language structure: an outline of the visual communication systems of the American deaf // Journal of Deaf Studies and Deaf Education. 2005. Vol. 10(1), pp. 3-37.

15. Wixtrom C. Two views of deafness // Deaf American. 1988. 38(1), pp. 3-10.

\section{ДАННЫЕ ОБ АВТОРАХ}

Галиева Дина Аслямовна, доцент, к. филол. н.

Уфимский ЮИ МВД России

ул. Муксинова, 2, г. Уфа, 450103, Российская Федерация galiva_dina@mail.ru

Науразбаева Лилия Викторовна, старший преподаватель Уфимский ЮИ МВД России ул. Муксинова, 2, г. Уфа, 450103, Российская Федерачия lilianv1979@mail.ru

\section{DATA ABOUT THE AUTHORS}

Dina A. Galieva, Associate Professor, Ph.D.

Ufa Law Institute of the Ministry of Internal Affairs of Russia 2, Muksinova Str., Ufa, 450130, Russian Federation galiva_dina@mail.ru ORCID: 0000-0003-3299-0443

Liliya V. Naurazbaeva, Senior Lecturer

Ufa Law Institute of the Ministry of Internal Affairs of Russia 2, Muksinova Str., Ufa, 450130, Russian Federation lilianv1979@mail.ru ORCID: 0000-0002-1970-3617 